\title{
Afro-Caribbean and Indigenous Religions as subject in Caribbean
}

\author{
Rachelle Sanicharan \\ University of Toronto \\ FAS [Canadian Studies Specialist]
}

\section{A B S T R A C T}

Historically, the presence of religion in art is one that is very common and well documented. Like all art, the images and various projects produced, they all are up to the viewers interpretation, with underlining messages throughout. Religion being such a major influence in many different cultures, it isn't surprising that there is such a connection to art and religion. This is true when looking at the art produced in the Caribbean or about the Caribbean, and also by the art produced by Caribbean artists. This research seeks to demonstrate some of the various Caribbean visual arts that have been produced and the portrayal or influence of religion presented, ranging from pre-colonization to post-colonization visual art projects. In turn, this will present the influence that religion has had in the Caribbean and how this has affected Caribbean communities, whilst also highlighting the lack of representation of

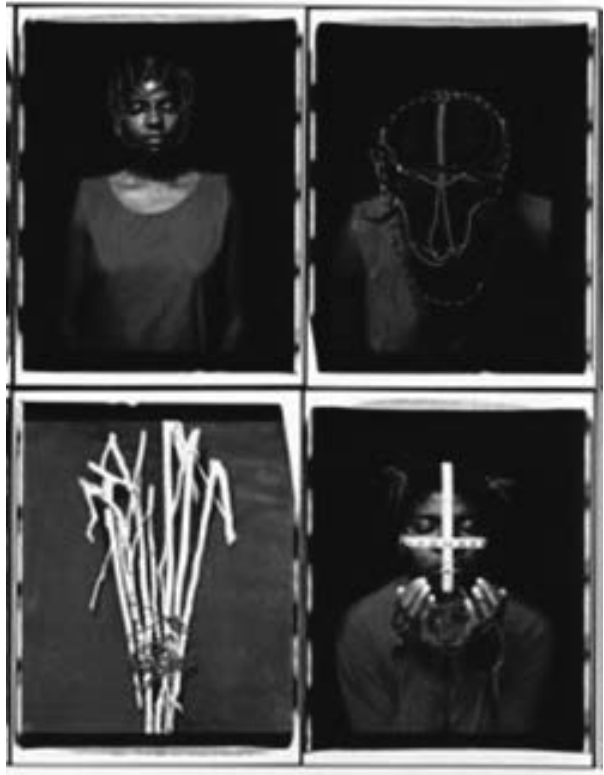

Keywords: Caribbean Visual Art, Caribbean Religions some common religions that are present in the Caribbean today.

\section{B I O}

Rachelle is a fourth-year student as a Canadian Studies Specialist at St. Michael's College University of Toronto. She is an Indo-Guyanese Canadian woman who has a particular interest in researching, recording, and preserving her Indo-Caribbean culture by constantly engaging with Caribbean communities, especially through the non-profit organization that she volunteers with called, Brown Gyal Diary. Brown Gyal Diary's mission is to create a space primarily for Indo-Caribbean women to share their experiences and histories to create recognition and to preserve our culture. Her inspiration towards engaging in Caribbean based work, is mostly linked to her love for family.

(C) 2021 Rachelle Sanicharan

Caribbean Studies Students'Union, Canada - https://jps.library.utoronto.ca/index.php/cquilt/ 
Historically, the presence of religion in art is one that is very common and well documented. Like all art, the images and various projects produced, they all are up to the viewers interpretation, with underlining messages throughout. Religion being such a major influence in many different cultures, it isn't surprising that there is such a connection to art and religion. ${ }^{1}$ This is true when looking at the art produced in the Caribbean or about the Caribbean, and also by the art produced by Caribbean artists. The Caribbean has an intensive and tragic history due to colonialism that include and is not limited to the mistreatment of Indigenous populations like the Ciboney, Arawak, and Carib peoples throughout the Caribbean, the African Slave Trade, as well as Indian and Chinese Indentureship. Moreover, European powers like the British, the Spanish, the French, the Dutch, and the Portuguese, all played a part in the Caribbean's complex history. Due to the influence of these colonial powers, the history, culture, rituals and spiritual beliefs of Indigenous communities, as well as peoples that were brought to the Caribbean through slavery and indentureship, there is a wide range of religious practices and beliefs that are practiced in the Caribbean. Some of these religious practices are the subject of Caribbean visual art. This research seeks to demonstrate some of the various Caribbean visual arts that have been produced and the portrayal or influence of religion presented, ranging from pre-colonization to post-colonization visual art projects. In turn, this will present the influence that religion has had in the Caribbean and how this has affected Caribbean communities, whilst also highlighting the lack of representation of some common religions that are present in the Caribbean today. I will not be discussing the multitude of religions that were practiced throughout the history of the Caribbean but I will be discussing the religions that are commonly referenced as being Caribbean religions, as well as religions that are most practiced in the Caribbean today.

One religious practice that was present in the Caribbean before colonialism, was the use of Zemís. Zemís are considered sacred symbols that were sometimes physical objects like the "Taíno Cotton Reliquary (Zemí)", which reflects a human effigy in embroidered cotton, but other Zemís were also made with different types of wood that was carved to create animal and/or human resemblance? Zemís are very closely linked to the worship of one's ancestors. ${ }^{3}$ Having detailed Zemís signified one's close relation to the supernatural world. Some Zemís were said to have had supernatural powers that included making it rain, making things grow and the Zemí even speaking to its owner. ${ }^{5}$

\footnotetext{
${ }^{1}$ Bosman, Frank G. "When Art is Religion and Vice Versa. Six Perspectives on the relationship between Art and Religion. " The Theological Journal of Emanuel University, vol. 18 no. 3, 2020, p. 3-20: Sciendo, doi:10.2478/perc-2020-0013.

${ }^{2}$ Maestri, Nicoletta. “A Columbian Discovery: 2,000 Year Old Zemi Artifacts of the Caribbean.” ThoughtCo, 23 Oct. 2019, www.thoughtco.com/zemis-ritual-objects-of-ancient-taino-173257.

${ }^{3}$ Roe, Peter G. "Walking Upside-Down and Backwards: Art and Religion In The Ancient Caribbean." The Oxford Handbook of the Archaeology of Ritual and Religion, 2011. Oxford University Press, doi:10.1093/oxfordhb/9780199232444.013.0034

${ }^{4}$ Mastri, Nicoletta.

${ }^{5}$ Roe, Peter G.
} 
Religious practices using Zemís were found across the Greater Antilles, with significant findings in Dominican Republic, Haiti and Cuba. ${ }^{6}$ Since these Zemís could be found in many countries in the Caribbean, they are well documented and are considered art pieces, some being preserved and displayed in museums. The spiritual practice with Zemís' is something that is notably recognized as a Caribbean religion.

As colonization occurred, the development of other religious practices became common in the Caribbean. One of the religions that is known for its relationship and connection with the Caribbean, is Obeah and relatives; Vodou, Palo and Santería which are derivatives of African spirituality and variations arguably due to the nature of colonialism. These practices are similar to each other and they have been closely linked with sorcery and even dark magic ${ }^{7}$ There are many different variants of the practice of Obeah, and so the religion has both a positive and negative reputation and it is still apparent in the Caribbean today. Obeah's portrayal as witchcraft however, is one way that Europeans furthered the 'othering' of Afro-Caribbean communities who often practiced Obeah for healing and divinity. ${ }^{8}$ The practice of Obeah and its relatives is shown in Caribbean visual art and it demonstrates the progression of European influence in the Caribbean. African spirituality has left an indelible mark of Caribbean religiosity. Derivatives of these belief systems such as Obeah, Vodou, Palo and Santería all have a basis in magic witchcraft and sorcery. For Europeans however, the connection to 'dark magic' played an important role in the othering of Afro-Caribbean communities who often practiced these religions as a source of healing and divinity. Europeans feared these systems because it made assimilation less likely.

Santería is an Afro-Cuban religion that is generally related to work with magic, witchcraft and sorcery, similarly to Obeah. In Maria Magdalena Campos-Pons work, she presents a prominent figure in Santería religion; Abridor de Caminos (The one who opens the path). ${ }^{9}$ Abridor de Caminos is closely related to Elegua, the most important orisha or deity in Santería. ${ }^{10}$ Elegua was the first orisha, a messenger between the divine world and human world, effectively the leader of the crossroads, and thus, nothing could be done in the worlds without Elegua's permission!1 Elegua is considered to be a trickster and is the force behind growth and divinity, she is represented by red, white and black, which are the same colours that are depicted in Campos-Pons work, Abridor de Caminos. ${ }^{12}$ In this work, she presents symbols of being at a crossroad, whether

\footnotetext{
${ }^{6}$ Mastri, Nicoletta.

7 Paton, Diana. The Cultural Politics of Obeah: Religion, Colonialism and Modernity in the Caribbean World, Cambridge University Press, Cambridge, 2015.

${ }^{8}$ See note 7 above.

${ }^{9}$ MOCRA, et al. "Episode 7: Maria Magdalena Campos-Pons.” Saint Louis University, Nov. 2013, www.slu.edu/mocra/voices-podcast/episode-7-maria-magdalenacampos.pons.php.

${ }^{10}$ See note 9 above.

${ }^{11}$ See note 9 above.

${ }^{12}$ See note 9 above.
} 
that is a literal cross spanning her face or her feet being separated and pointed in different directions between what appears to be white twig pieces. ${ }^{13}$ Interestingly, the colours that represent this orisha, are colours that many people associate with the devil or with evil, and having the orisha being the owner of the crossroads, where there is mythology of crossroad dealers being demons or evil. ${ }^{14}$ This is yet another way that religions such as Santería and Obeah are darkly portrayed. Obeah is not an organized religion like some of its western counterparts, but it is a result of the African diaspora in the Caribbean, it is a creolized religion that has European and African influence. Similarly, Santería is also a direct result to enslaved Africans whom were brought from Nigeria and Western African nations, that mixed their Yoruba religion with elements of Roman Catholic influence from plantation owners 15 Arguably, Santería contains elements of European, African, and Indian spiritual practices ${ }^{16}$ The religion's presence in the Caribbean was also a way to demonstrate the difference between Europe and the Caribbean. Overall, religions such as Obeah and Santería are creolized practices that occurred due to colonization in order to create even more of a divide between Afro-Caribbean peoples and Europeans, something that is still apparent throughout the Caribbean today. The influence of this subjugation and forced integration may be seen through art pieces which progressively show increasing European influence in religious practices throughout the Caribbean.

Through colonialism religions such as Christianity were brought to the Caribbean. Though we see some factors of Christianity that was referenced in African diaspora religions, in some instances Christianity has demonstrated influence on Caribbean art directly without being combined with other practices. For example, in José Nicolás de Escalera's work, Santa Bárbara, we are shown that Christianity has become a part of the people who inhabit the Caribbean." This painting not only showcased artistic techniques from Europe, but it also depicts St. Barbara, a Christian saint whom was a martyr and is sometimes connected to lightning, seeing as after her father killed her for being a Christian when he was a Pagan, he was struck by deadly lightning as he arrived home. ${ }^{18}$ St. Barbara is referenced in the Catholic Church, the Eastern Orthodox Church and other Christian denominations. She is also referred to as one of the fourteen Holy Helpers. In José Nicolás de Escalera's work, St. Barbara is pictured with a palm leaf that many times is pictured with virgin martyrs. Most of José Nicolás de Escalera's work was religious based or it was portraits of colonialist. His work shows

\footnotetext{
${ }^{13}$ See note 9 above.

14Davis, Andrea. Canadian Journal of Latin American and Caribbean Studies / Revue Canadienne Des Études Latino Américaines Et Caraïbes, vol. 31, no. 61, 2006, pp. 261-263. JSTOR, www.jstor.org/stable/41800310.

${ }^{15}$ See note 9 above.

${ }^{16}$ See note 14 above.

${ }^{17}$ Benítez, Virginia Alberdi. “WHERE IS THE STARTING POINT OF CUBAN ART?” ArteMorfosis, 14 Nov. 2016, www.artemorfosis.com/where-is-the-starting-point-of-cuban-art/.

${ }^{18}$ See note 17 above.
} 
the influence that Europeans had in the Caribbean, the art techniques that were labelled European, the presence of European religion and the paintings of Saints, shows how Christianity began to spread in the Caribbean. Today, the presence of Christianity is shown throughout Caribbean countries, ${ }^{1}$ being the most popular religion in the Caribbean.

Though many art pieces have been created that present the history of religious practices in the Caribbean, there are in fact some religions that aren't as commonly acknowledged in visual art, as being part of Caribbean history. The visual art that has been discussed thus far mostly speaks of the influence that colonialism has had on Afro-Caribbean religious practices, but I have not mentioned any popular Indo-Caribbean visual art pieces. Though the history of Indian indentureship isn't as long as the history of the African Slave Trade, Indian people first arrived in the Caribbean, British Guiana in 1838, arriving at what is now called, Guyana. Indians were brought to the Caribbean after the abolition of slavery, effectively replacing slavery with indentured labourers who had contracts. Interestingly, many visual art pieces were created after the arrival of Indians in the Caribbean, yet their presence isn't as reflected in visual art as Afro-Caribbean peoples and so, the religions that many Indo-Caribbean peoples practiced aren't often shown in art either. Seeing as though the history of Indo-Caribbean peoples goes back over 180 years, this part of colonialist history isn't very reflective in Caribbean art. The most popular religions that Indo-Caribbe-
Caribbean peoples' practice that is not often represented in art is Hinduism and Islam.$^{20}$ This is shown especially in different countries in the community like in Guyana and Trinidad and Tobago, were the religious practices of Indo-Caribbean peoples are also celebrated by Afro-Caribbean peoples who do not identify with these religions and vice versa. For example, in Guyana, both Indo-Guyanese peoples who are and are not Hindu, and Afro-Guyanese peoples whom are not Hindu, celebrate the Hindu festival, Pagwah also known as Holi. Moreover, Indo-Guyanese people who are not Christian, still celebrate Easter by flying kites. Both Pagwah and Easter are celebrated by the whole population of Trinidad and Tobago no matter what religion you identify with. Through these religious holidays, it brings unity to countries who have historically been divided by their race and religions, demonstrating how religion does positively affect Caribbean communities.

Though Caribbean art is reflective of some religious practices in the Caribbean, there is still a lack of popular recognition for certain religions that are a part of the Caribbean. None of the less, Indigenous religions are still present in Caribbean visual art and the impact of colonialism in the Caribbean is reflected in these visual art pieces as we see the influence that European practices began to have in the Caribbean. Creole religious practices like Obeah and Santería show primarily the combination of European and African spiritual practices. As colonialism contin-

\footnotetext{
${ }^{19}$ See note 17 above.

${ }^{20}$ Scher, Philip W. "Race and Religion in the Caribbean.” Anthropological Quarterly, vol. 77 no.4, 2004, p. 831 -834: Project MUSE, doi:10.1353/anq.2004.0065.
} 
continued, we see the influence that

Christianity has also had in the Caribbean and that is also reflected in Caribbean.

Through these pieces of art, we are shown the various stories of displacement, creolization, belonging, and tradition. We are shown a snippet of the complex and long history of the Caribbean and the various religions that are/were practiced. In turn, this depicts the different communities that are in the Caribbean and the different ethnicities, races, and cultures that are followed. The Caribbean is very multicultural and that is reflected through the art and religions throughout the region. 


\section{Works Cited}

Benítez, Virginia Alberdi. "WHERE IS THE STARTING POINT OF CUBAN ART?" ArteMorfosis, 14 Nov. 2016, www.artemorfosis.com/where-is-the-starting-pointof-cuban-art/.

Bosman, Frank G. "When Art is Religion and Vice Versa. Six Perspectives on the Relationship between Art and Religion." The Theological Journal of Emanuel University, vol. 18 no. 3, 2020, p. 3-20: Sciendo, doi:10.2478/perc-2020-0013

Campos Pons, Maria M. Abridor de Caminos (Road Opener), 1997, Web, Cuba.

Cotton reliquary (Zemi), Taino, n.d., Web, Dominican Rep.

Davis, Andrea. Canadian Journal of Latin American and Caribbean Studies / Revue Canadienne Des Études Latino-Américaines Et Caraïbes, vol. 31, no. 61, 2006, pp. 261-263. JSTOR, www.jstor.org/stable/41800310.

De Barros, Juanita. Review of Obeah and Other Powers: The politics of Caribbean religion and healing ed. By Diana Paton, Maarit Forde. Journal Colonialism and Colonial History, vol. 14 no. 3, 2013. Project MUSE, doi:10.1353/cch.2013.0048

De Escalera, José Nicolás. Santa Bárbara, 2nd half XVIII c (2), Web, Cuba.

"Jose Nicolas De La Escalera (1734-1804)." Jose Nicolas De La Escalera | Art Experts, www.artexpertswebsite.com/pages/de-la-escalera.php.

Maestri, Nicoletta. "A Columbian Discovery: 2,000 Year Old Zemi Artifacts of the Caribbean." ThoughtCo, 23 Oct. 2019, www.thoughtco.com/zemis-ritual-objectsof ancient-taino-173257.

MOCRA, et al. "Episode 7: Maria Magdalena Campos-Pons." Saint Louis University, Nov. 2013, www.slu.edu/mocra/voices-podcast/episode-7-maria-magdalenacampos pons.php.

Paton, Diana. The Cultural Politics of Obeah: Religion, Colonialism and Modernity in the Caribbean World, Cambridge University Press, Cambridge, 2015.

Roe, Peter G. "Walking Upside-Down and Backwards: Art and Religion In The Ancient Caribbean." The Oxford Handbook of the Archaeology of Ritual and Religion, 2011. Oxford University Press, doi:10.1093/oxfordhb/9780199232444.013.0034

Scher, Philip W. "Race and Religion in the Caribbean." Anthropological Quarterly, vol. 77 no.4, 2004, p. 831-834: Project MUSE, doi:10.1353/anq.2004.0065

Traverso, V.M. "How to Recognize the Symbols of Martyrdom in Art." Aleteia, 16 Oct. 2020, aleteia.org/2020/10/16/how-to-recognize-the-symbols-of-martyrdom-in-art/. 